\title{
THE ANALYSIS OF GRAMMATICAL ERRORS SPOKEN BY MALANG TOURIST INFORMATION CENTER'S CUSTOMER SERVICES
}

\author{
Linda Aprelia Setiorini \\ linda.a.setiorini123@gmail.com \\ University of Kanjuruhan Malang
}

\begin{abstract}
This research analyzes the grammatical errors in spoken English of customer services of Malang Tourist Information Center. The objectives of this research are to determine the types of errors and the cause of errors spoken by the customer services. The data were collected from four customer services by recording their conversation between them and the tourists. The study only focuses on the customer service's utterances. The design of this research is descriptive qualitative research and the instrument is researcher herself. The finding of this research showed that the most dominant error was error of omission with 44 numbers (44\%), followed by error of selection with 38 numbers (35\%), error of ordering with 14 numbers $(12 \%)$, and error of addition with 8 numbers $(9 \%)$. The research also investigated that the causes of errors spoken by customer services were interlingua and intralingua transfer. Interlingua transfer was considered as the major cause of errors of customer services of Malang Tourist Information Center.
\end{abstract}

Keywords: grammatical errors, error analysis, utterances

\section{INTRODUCTION}

Speaking required much repetition to speak, especially for foreign language learner that is learning to speak fluently. Some people assumed that studying a language, one must be able speak in that language, but actually speaking is difficult. Speaking is a complex requiring the simultaneous use of a number of different abilities, which develops at the different rates. Either four or five components are generally recognized in analysis of the speech process (Sharees and Chauday, 1997) that are:

1. Pronunciation (including the segmental features-vowels and consonant-and the stress and intonation patterns)

2. Grammar

3. Vocabulary

4. Fluency (the ease and speed of the flow of speech)

5. Comprehension

Since speaking English is important, it has become increasingly necessary for employee's working, especially in tourism industry that is booming in this few years. Furthermore, globalization has increased competition in tourism market and destinations are exposed. Due to this reason, human resource development is critical to the success of tourism in many markets. In tourism industry supply and demand side must communicate perfectly in order to ensure quality and needed performance standards. In business tourism, practice oral communication is a bit higher than written communication, but both categories are rated high (Kay and Rusette: 2000).

In Malang, there is a Malang Tourist Information Center that is a travel agent which provides the information and tour services through Malang tourist destination places. There are four customer services that service the customer. As the customer 
service, they must be able to speak English fluently because we know exactly that almost the customers are foreign people and come from many countries in the world. In this case, the researcher finds some errors that spoken by them. Mostly, they do the errors in grammar while they are delivering the information through the customer.

Based on the researcher's perspective, knowing grammar is very important. Grammar is the whole system and structure of a language in general. When we are good in grammar, the sentences become easily to be understood by the listeners. The grammar of a language is a description of the ways in which the language uses patterns of structure to convey the meaning, so it would be impossible to learn language effectively without knowing grammar because grammar helps learners to identify grammatical forms, which serves to enhance and sharpen the expression of meaning. The importance of grammar is also strengthened by Kalend (2006) who said "Having a good grammar system of a language, learners will be helpful in delivering their ideas, messages and feelings either to the listeners or readers, language without grammar would be disorganized and causes some communicative problems, for example we cannot say something in passive sentence using English if we do not know the grammar concept of passive voice". According to Greenbaum \& Nelson (2002) "Grammar refers to the set of rules that allow us to combine words in our language into larger units. Some combinations of words are possible and others are not". He added that grammar is the central component of a language.

When we are learning the other languages, sometimes it happen some errors, especially errors in grammar. According to Heydari \& Bagheri (2012; as cited in Brown, 1994, as cited in Hasyim, 2002) classified sources of errors into the flowing categories:

1. Interference transfer, which is the negative influence of the learner's mother tongue.

2. Intralingua transfer, which is the negative transfer of the items within the target languages. In other word, in the incorrect generalization of the rule within the target language.

3. Context of learning, which overlaps both types of transfers.

4. Communication strategies, which are the conscious employment of the verbal mechanism for communicating an idea when linguistic form are not available to the learner for various reason.

Actually, errors are different from mistakes. Errors and mistakes are commonly done by the second language learners and foreign language learners. Without deep understanding, the learners usually attend to see the errors and mistakes similarly. Brown (20017) says that all native speakers make mistakes, or have a "performance lapse". He also states that a mistake refers to a performance error that is either a random guess or a "slip", in that it is a failure to utilize a known system correctly. Brown adds that all people make mistakes in both natives and second language situation. Therefore, whether they are native speakers or second language learners, they probably could make mistakes in producing the language. Mistakes occur because the learners know the system but they fail to use it. Meanwhile, errors according Brown (20017) are the result of one's systematic component. An error reveals a portion of learner's competence in target language. The English learners are usually not able to make any correction of their errors by themselves. Thus, the English learners could probably make errors 
because they do not know the English grammar well. The learners think that they make the right English even though they do not know because their language system says so.

Based on the explanation above, the researcher is interested in analyzing the utterance that is spoken by the customer services of Malang Tourist Information Center (MTIC) while they are delivering or giving the information through the foreign customers. The researcher investigates the grammatical errors of their utterances only. This research guided though following major questions:

1. What are types of grammatical errors spoken by Malang Tourist Information Center's Customer Services?

2. What are the factors that influence their grammatical errors?

\section{METHOD}

This method of this study is descriptive qualitative method. It is based on the research focus to analyze the grammatical errors that was spoken by the customer services of Malang Tourist Information Center. The data of this study were taken from the utterances of the customer services while delivering the information to the tourists who came to Malang Tourist Information Center on October to December 2017. The customer services of Malang Tourist Information Center are four people.

\section{FINDINGS}

This study is investigated to know the kind of grammatical error that is spoken by customer services of Malang Tourist Information Center. This research attempted to describe those errors. According to the data analysis, 104 errors were found from 171 utterances. Among four types of error, error of omission was the most frequent error with followed by error of selection, then error of ordering, and the least frequent error was error of addition. The result can be seen from the table below.

Table 1. Frequency of types of error spoken by Malang Tourist Information Center's customer services.

\begin{tabular}{|l|l|l|l|}
\hline No & Types of Error & Frequency & Percentage \\
\hline 1 & Error of Omission & 46 & $44 \%$ \\
\hline 2 & Error of Addition & 9 & $9 \%$ \\
\hline 3 & Error of Selection & 36 & $35 \%$ \\
\hline 4 & Error of Ordering & 13 & $12 \%$ \\
\hline \multicolumn{2}{|l|}{ TOTAL } & 104 & $100 \%$ \\
\hline
\end{tabular}

The Factors that Influence the Grammatical Errors of Malang Tourist Information Center's Customer Services were interlingua transfer and intralingua transfer. It based on the theory of Heydari \& Bagheri (2012). The major cause of errors was caused by interlingua transfer followed by intralingua transfer. 


\section{DISCUSSION}

\section{Types of Grammatical Error}

This research found there were 104 grammatical errors from 171 utterances. Those were 46 errors of omission, 9 errors of addition, 36 errors of selection, and 13 errors of ordering. Error of omission appeared more than other types of error because the customer service did not pay intention more in producing the utterance. They omitted some items in a sentence that is actually needed in well form sentence. The abundance of omission errors can be caused by the minimum knowledge about the right structure in English because of the lack of knowledge about the structure. This research was supported by the previous study which is conducted by Safrida \& Kasim (2016). They found that the error of omission was the highest frequency produced by the EFL undergraduate students.

The second highest frequency of grammatical errors that were made by the customer services were error of selection which reached $35 \%$ from the total of errors. Selection errors were the errors that were characterized by the use of wrong form in morpheme and structure that can be caused by the minimum knowledge about the pattern. This finding was seemed to be same as the theory of Corder (1981) states that "Errors are things made by beginner of second or other language learners who do not yet have a full command of language system. Thus, the English learners could probably make errors because they do not know the English grammar well".

The third highest frequency of grammatical errors made by the customer services was the errors of ordering which reaches $12 \%$ from the total of errors. Ordering errors were characterized by the incorrect placement of morpheme or group of morpheme in an utterance or sentence. Based on the data that had been identified by the researcher, the customer services had ever made the wrong placement such in constructing sentence. This error happened because the customer service's mother tongue was different from English in the structure of placement of morphemes. This finding was the same as the theory of Dulay \& Burt (1974) stated "The development of errors which are similar to first language (L1)".

The least grammatical error made by the customer services were addition which reach $9 \%$ from the total of error. Addition errors were characterized by the presence of item that must not appear in well-formed utterance/sentence. According to Greenbaum and Nelson (2002) "Grammar refers to the set of rules that allow us to combine words in our language into larger units. Some combinations of words are possible and others are not". So, this theory gave the clear explanation that the customer services did the errors because they were careless about the rule in English grammar.

\section{Sources of Error}

The researcher used the theory of Heydari \& Bagheri (2012) classified errors into four categories according to their causes, which are interlingua transfer, intralingua transfer, context of learning, and communicative strategy. From 104 errors that has found by the researcher, it shown that there were only two sources of errors done by the customer services: interlingua transfer as the majority of caused of error, and followed by intralingua transfer.

The majority of source of errors was caused by interlingua transfer. The error happened because the influences of the customer service's mother tongue or their L1 
structure which had different pattern from English language. This finding supported by theory of Dulay \& Burt (1974), they stated that "interference errors reflect the structure of the L1".

The error caused by intralingua transfer occurred in smaller number. Intralingua transfer happened because of the customer service's incomplete knowledge about target language or English language. It means that the errors happened because their ability in speaking English.

\section{CONCLUSION AND SUGGESTION}

The researcher found some findings in analyzing grammatical errors which was spoken by customer services of Malang Tourist Information Center. First, the researcher found there were 104 errors divided in to four types. There were (1) error of omission 44 errors or $42 \%$, (2) error of addition with $37 \%$ or 38 errors, (3) error of selection with 14 errors or $13 \%$ and (4) error of ordering with only 8 errors or $8 \%$.

The second finding was about the factors that influence the grammatical errors of customer services of Malang Tourist Information Center. There were two main factors of their errors: interlingua and intralingua transfer. The most dominant of cause of error was interlingua transfer.

This research still has many weaknesses. It is still limited on the grammatical errors spoken by customer service of Malang Tourist Information Center. On the other hand, there are still a lot of informations that is able to be researched. Hoping the university students can explore more about grammar in other fields.

\section{REFERENCES}

Brown, H. D. 2007. Principle of Language and Teaching. (Fifth ed.). Pearson Education, Inc: United States of America.

Chomsky, N. 2002. Language learning. Belmot: Thomson Learning.

Corder, S. P.1981. Error Analysis and Interlanguage. London:Oxford University Express.

Dulay, C., \& Burt, K. (1974).Error and strategies in child second language acquisition.

Greenbaum, S \& Nelson, G. 2002. An Introduction to English Grammar (Second ed.). Essex: Longman.

Heydari, P. \& Bagheri, M. S. (2012). Error Analysis: Sources of L2 Learner's Error. Theory and Practice in Language Studies.

Hojati, A. (2013). An Investigation of Errors in the Oral Performance of Advancedlevel Iranian EFL Students, 4(4), 171-180.

Kalend. O. Grammar in use (speech presented at seminar farewell at BASIC ENGLISH COURSE/BEC pare Kediri, Indonesia, 2006). 
Kay, T. R \& Russette, B. 2000. Progression analysis (PA): investigating writing strategies at the workplace. Journal of Pragmatics, 35, 907-921.

Safrida \& Kasim. 2016. Grammatical Errors: An Analysis in speaking produced by EFL Undergraduate students. Vol.1. No.1.

Sharees Chauday. Testing Spoken English, (English Teaching Forum, 1977), vol 36. p22. 